\title{
Father Roles in Islamic Perspective on Islamic Senior High School in Jakarta
}

\author{
Bunyanul Arifin* \\ Doctoral Program of Islamic \\ Education, Graduate School, \\ University of Ibn Khaldun, \\ Bogor 16164, Indonesia
}

\author{
Endin Mujahidin \\ Doctoral Program of Islamic \\ Education, Graduate School, \\ University of Ibn Khaldun, \\ Bogor 16164, Indonesia
}

\author{
Zainal Abidin Arief \\ Doctoral Program of \\ Islamic Education, \\ Graduate School, \\ University of Ibn Khaldun, \\ Bogor 16164, Indonesia
}

*Corresponding author: abunyanul@yahoo.com

\begin{abstract}
The previous study showed that the quality of father-child relationship could predict the quality of family relationship. Father involvement were positively affecting child development. This study aimed to identify father roles on children in Islamic perspective. The study was conducted in Islamic Senior High School in West Jakarta. Five hundreds student from class IX were used in this study, and selected by using cluster random sampling method. Data were collected using in-depth interview and self-report with questionnaire as the tools. Father roles consist of six dimensions: (1) leader, (2) economic provider, (3) protector, (4) educator, (5) playmates, and (6) friend. This study found that father's role as a leader, economic provider, and protector were the roles that most felt by children. Meanwhile, father's role as an educator, playmates, and friend were the roles that less felt by children. Based on the result of the study, it is important to provide parenting education programs (training, seminars, and counseling) for parents especially father to enhance father roles in child live.
\end{abstract}

Keywords: economic provider, father roles, leader, protector

\begin{abstract}
Abstrak
Penelitian terdahulu menegaskan bahwa kualitas hubungan ayah-anak dapat menentukan kualitas hubungan di dalam keluarga. Keterlibatan ayah dalam kehidupan anak mampu memberikan pengaruh positif terhadap perkembangan anak. Penelitian ini bertujuan untuk mengidentifikasi peran ayah terhadap anak dalam persektif pendidikan Islam. Penelitian dilakukan di sekolah Madrasah Aliyah Negeri (MAN) di Jakarta Barat. Penelitian ini melibatkan 500 siswa kelas IX dari lima sekolah MAN di Jakarta Barat yang dipilih dengan menggunakan teknik cluster random sampling. Pengumpulan data penelitian dilakukan dengan menggunakan teknik wawancara mendalam dan self-report dengan alat bantu kuesioner. Peran ayah dalam penelitian diukur dalam enam dimensi yaitu: (1) pemimpin, (2) penyedia kebutuhan ekonomi, (3) pelindung, (4) pendidik, (5) teman bermain, dan (6) sahabat. Penelitian menemukan bahwa peran ayah sebagai pemimpin, penyedia kebutuhan ekonomi, dan pelindung adalah peran yang paling besar dirasakan oleh anak. Sementara itu, peran ayah sebagai pendidik, teman bermain, dan sahabat adalah peran yang masih kurang dirasakan oleh anak. Berdasarkan hasil penelitian, diperlukan adanya program-program pendidikan (pelatihan, seminar, dan konseling) pengasuhan mengenai peran orang tua khusunya peran ayah.
\end{abstract}

Kata Kunci: pelindung, pemimpin, penyedia kebutuhan ekonomi, peran ayah 


\section{Introduction}

Parental education and parenting are the basic foundations for the formation of individual character and personality, as well as being a key factor for individual success and happiness. The prevailing public outlook shows that mothers are the most responsible and responsible parties to the growth and development of children. The role and responsibility of the father in the growth and development of children is limited only as a provider of economic needs in the family. The view that the role of father to the child only as breadwinner breadwinner not only occur among ordinary people in general, but also among educated people (Sofar, 2008).

In the era before the 1970 s, studies and policies on family development were more dominated about the nuclear family that placed the father only as a breadwinner or in charge of economic needs. Meanwhile, the mother is in charge of care and parenting. The National Center for Education Statistics (NCES), a research and development institute at the US Department of Education, states that in recent decades, children's studies and child-related issues tend to focus only on mother-child relationships, and often forget relationships father-son (NHES, 1997). In fact, the father also has an important role in the process of child development. The results of a study conducted by Kurk (2012), a Professor of Social Sciences at British Columbia University, stated that the absence of a father role can cause 70.0 percent of drop out students from school, low academic achievement, students engaged crime and criminal acts (85.0 percent of juvenile in prison due to lack of father role), deviations of sexual behavior in adolescents (pregnant out of wedlock, free sex behavior, etc.), adolescents falling into narcotics and drugs, and teenagers not at home (90.0 percent teenagers who fled from home in the absence of the father's role in his life).

Michael E. Lamb, one of the pioneering scientists on the role of father, says that the father is the forgotten contributor because of his central but often forgotten role. Abandonment of the father role is equivalent to allowing bias in child development studies (Lewis \& Lamb, 2003). Erawati (2012) states that since Lamb's research published in the book, The Role of The Father in Child Development (1981), studies on the role of father then began to be widely practiced in the United States.

Books, scientific studies, theories or theories that discuss the father and various things related to the father is called fathering (father's role). Recognizing the importance of fatherhood to children, in 1995 President Clinton submitted a memorandum calling on all other important departments and institutions in the United States to focus and seriously turn fatherhood into a key issue in policy programs, policies and studies in the United States (NCES, 2001).

Some Western countries such as Britain, France and the United States are finally aware of and have placed the father as the most important and authoritative and influential person to wife, children and family property.

A father also plays a role in moral-spiritual growth and development as well as in the formation of child discipline (Parke \& McDowell, 2003). Pleck and Pleck (1997) in Parke \& McDowell (2003) also assert that this new pattern of father and child relationships is believed to lead to the maturity of family care and education that will greatly affect the child's character.

Fathering has grown and has been discussed as a scientific study, public discussion as well as a policy review since the 1990s (Darity, 2008). In 1981, Michael E. Lamb has made a formula about the three dimensions of the father's role to the child. 
Lamb divides the role of father in three dimensions: interaction, willingness of time, and responsibility (NCES, 2001). In other studies conducted by Jain, Belsky and Crnic (2015), the role of fathers is categorized into four types: (1) caregivers, (2) teachers and friends, (3) disciplinary controllers, and (4) supervisors. Meanwhile, according to Hart in Belsky \& Crcnic (2015), the father's role to his son is as: (1) breadwinner, (2) friends and playmates, (3) nurses, (4) teachers and role models, (5) and disciplinary controllers, (6) protectors, (7) dispatchers, and (8) as sources for children.

Another Fathering theory is given by Evans \& Fogarty (1999) which states that the role of the father can be called the Five Ps or five Ps, namely: (1) the solution giver; (2) playmates; (3) the penalty; (4) the giver; and (5) the provider. Rilley \& Shalala (2000) and Brown (2000) answer the question, "What's special about Father's Involvement?" And conclude that a father has a special role as: (1) role model as adult male, (2) 3) solution providers, (4) providers of financial needs and motivators. Hilliard (1996) formulated the role of father in relation to children into three factors: communication, commitment, and religion. Meanwhile, McAdoo (1993) considers that the role of father is as: (1) provider and provider of facilities; (2) the safeguard; (3) decision makers; (4) educators and experts on children; and (5) maternal assistants in care.

Another study of the role of fathers specifically linked to children's education at school was conducted by Seiderman in Slameto (2002) who stated that the father's role in children's education is: (1) spending as much time with the child as possible; (2) taking an active role in child development; (3) engaging in the child's education process; (4) be role models for children; (5) ensure the child is in good health. Slameto (2002) in his research on the role of fathers in children's education and their relationship with children's learning achievement divides the role of father into: (1) provider of learning facilities; (2) educators; (3) mentors; (4) models or examples.

The United States-based National Center on Father and Families (NCOFF, 2001) develops several indicators to measure the role of the father: (1) father presence or the presence of fathers in a child's life that includes engagement, availability, and responsibility, care-giving which includes care, care, health, and appearance; (3) social competence, which is an effort to develop the ability and social intelligence; (4) cooperative parenting, which is to build a positive relationship to optimize child development; (5) father's healthy living, which is a model in health, education and social behavior; and (6) material and financial contribution, which is to provide all financial and other material needs.

The National Center for Education Statistics (NCES, 2001), a research and development institute at the US Department of Education, released and summarized the role of father to child into seven areas which are summaries and conclusions from some of the opinions and research results of experts such as Amato (1987, 1996), McBride (1990), McBride and Mills (1993), Palkovitz (1997), Radin (1994), Volling and Belsky (1991). The seven roles of the father are: (1) the economic provider, the father as the provider of the economic needs of the family and children; (2) caregiver and nurturer, ie child care (bathing, cleaning, or feeding the child) and emotional care (kissing, caressing, embracing and calling her with a pet call); (5) friends and playmates, the father acts as a friend and playmate for the child, (6) monitors and disciplinarian, the father as the supervisor and who controlling the discipline, attitude, and behavior of children, and (7) protector, the role of father as a protector for children. 
The fathering theories mentioned above are built on the philosophy and scientific epistemology developed in the West which is certainly in several different aspects from Islamic scholarship which are derived from two things: (1) Divine source or revelation in the form of the Qur'an and Sunnah; and (2) human source of ijtihad and research efforts and studies conducted by human beings beneficial to humanity in general and not contrary to the principles of Islamic law (Ulwan, 2013).

Research and study of the role of father to child in Islamic perspective can be said is not enough. In general, books on the role of parents against children or Islamic Parenting is theoretical-philosophical such as the classic book of famous ulama Ibn Qayyim Al-Jauziyah (2005), Tuhfat al-Maudud Fi ahkam al-Maulud and also the book by Abdullah Nasih Ulwan, Tarbiyat Al-Aulad Fi al-Islam. Some of these books are still practical and applicable as written by Irawati Istadi (2014), Ihsan Baihaki Ibnu Bukhari (2013), Muhamad Fauzil Adzhim (2004), and others that are mostly general and not research and non-specific talking about dad.

The scientific work on the father's role from the Islamic point of view is in a dissertation by Baharits (1991) at Ummul Qura University, Saudi Arabia in 1991. This dissertation has been translated and published by Gema Insani publisher in 2007 under the title Educate Boys, while the original title of this paper is "Mas'uliah al-Ab alMuslim Fi Tarbiyah Al-Awlad Fi Marhalah At-Tufuliyah". However, Baharits (1991) focuses more on the role of fathers on boys in the childhood phase alone and only stops on concepts and theories alone, thus giving less facts relating to the role of the father in child development.

Based on the results of a study of the growing Fathering Theory and the study of the primary sources of Islamic teachings and the works of these scholars then the authors formulate the six theories of the role of the father:

1. The role of the father as the leader (leader), on the basis of the Qur'an An-Nisa (4:34), and the Sahih Hadith of Abdullah bin Umar RA: "Every one of you is a leader and every leader will be held accountable for he leads "(Al-Bukhari, 2014);

2. The role of the father as the provider of economic needs (economic provider), on the basis of Al-Qur'an letter of Al-Baqarah (2:23), QS an-Nisa (4:34), and QS At-Talaq (65: 7), and in a hadith to Sahih Bukhari narrated from Abu Mas'ud Al Ansari (Bukhari, 4932) and Abu Dawud (Ulwan, 2013);

3. The role of the father as a protector (protector), based on the texts of the Qur'an and Sunnah, among others, the story of Prophet Ibrahim a.s with his son Prophet Ismail a.s, the story of the Prophet Ya'qub a.s with his children including with his son Joseph a. Likewise includes the story of Noah a.s with his son Kan'an, and the story of Prophet Muhammad SAW in safeguarding and protecting his children as described in hadith and history books (Abadzhah, 2007);

4. The role of the father as educator, on the basis of Q.S Al-Jumu'ah (62: 2) and the hadith of Imam Muslim's narration from Jabir bin Abdullah (Muslim, 1994, p.692). Example and role model of father as educator for children of scholars and salafusshalih in Al-Muhaddithat book; The Women Scholars in Islam by Nadwi (2007);

5. The role of the father as a playmate, on the basis of the hadith which explains the attitude of the Prophet Muhammad who played with the children as with his children and grandchildren, Hasan, Husayn and Osama bin Zaid, and against other small children; 
6. The role of father as a friend (friend), on the basis that the Prophet SAW has given an example related to the role as a friend to the child as in the hadith Saheeh history of Imam Bukhari.

The father's role theory in this Islamic perspective emphasizes the aspect of leadership that does not get special emphasis from existing fathering theories. The most important leadership aspect of a father in this case is exemplary that is born out of pure or good attitude of life modeled by the child and family. Parameter is the obedience of worship runs accompanied by morals or behavior that is commendable. As for the other five aspects of the writer seeks to find the basis and footing of the sources of Islamic teachings as mentioned above.

This study aims to identify the role of father to children in the perspective of Islamic education as measured by six dimensions of leaders, providers of economic needs, protectors, educators, playmates, and friends. This study is important to change the old pardigma that assesses that the role of the father in the life of the child is only limited to the aspects of the responsible economic needs. Based on the theory of Islamic Fathering that originated in Islamic teachings, it should be a Muslim father can play other roles besides the role as a breadwinner

\section{Methods}

This research is descriptive research with cross sectional design. The location of the research was chosen purposively, namely Aliyah Islamic Senior High School in West Jakarta. West Jakarta was chosen because it has the highest number of Aliyah Islamic Senior High School schools as many as 6 (six) schools. The study was conducted from September 2015 to March 2016.

The study population is all Aliyah Islamic Senior High School students in West Jakarta. Examples of research are IX class students majoring in Science, Social Studies, and Religion. Sampling was done by using cluster random sampling method based on school and department. The number of examples involved in the study was 500 students.

Research data obtained through the method of in-depth interview and self-report with a questionnaire tool. The variables studied in this study include sample characteristics, school characteristics, and father role. Characteristics of examples of age, sex, religion, and economic status. The role of the father consists of six dimensions of leaders, providers of economic needs, protectors, educators, playmates, and friends.

Processing and data analysis is done by using Microsoft Excel program. The role of the father is measured by using a questionnaire containing 40 items of questions with five answer choices from never to always. Data analysis used in this research is descriptive analysis.

\section{Characteristics of samples}

\section{Result}

Five hundred samples involved in the study consisted of 195 boys and 305 children. Examples are in the adolescent age period with an age range of 14 to 17 years. From the religious point of view all the respondents are Muslims, with the family's economic level coming from middle and lower middle class families. 


\section{Characteristics of the school}

Characteristics of schools are public schools under the auspices of the Ministry of Religious Affairs. Considering the State schools get subsidies from the government then the feasibility of building and facilities and infrastructure is good enough and adequate to support the process of good teaching and learning.

Based on the results of field observation, it is found that the characteristics of the school in which the research is a religious-based school that emphasizes the aspects of religiousity and noble character. This can be seen from the vision, mission, program and discipline and uniform clothing used by teachers and schools. The existence of schools in the city of Jakarta a bit much certainly give impact and influence to students.

\section{Dimensions of Father's Role as Leader (Leader)}

Table 1 shows the results of an indicator that is always and not always done by the father in the role of leader. There are five indicators of the nine indicators that have the most proportion included in the indicator that is always done by the father as a leader. The five indicators are to perform the five-time prayer $(71.8 \%)$, sanction if the child leaves the prayer $(30.2 \%)$, be affectionate and fair to the child $(61,0 \%)$, pray for the child's good ( $81.2 \%$ ), are eligible to imitate and imitate children (35.8\%), and reprimand and sanction if the child committed violence $(53.0 \%)$. Furthermore, there is one indicator with the highest proportion that dad never did, ie taking a child's school report $(31.4 \%)$. This means there is a perception that the activity of taking school report cards is not an important part of the father role as a leader. For the indicator reminding the child to pray it has the most proportion on the occasional choice $(28.4 \%)$, whereas to sanction if the child leaves the prayer is always the choice with the highest proportion $(30.2 \%)$. This means that there is an imbalance in the role of the father as a leader especially with regard to religious aspects.

Based on the index, the indicator on the role dimension of the father as the leader who has the highest index is to pray for the good of the child $(92,6)$. This shows that the role of father as a leader feels the child's goodness becomes an important part of his responsibility as a leader in the family so that, one way is the father always pray for the good of his son. Meanwhile, the lowest index is to take school children's report $(41,9)$ which means that this indicator is less or even not part of responsibility of father role as leader.

\section{Dimensions of Father's Role as Provider of Economic Needs (Economic Provider)}

The role of the second father in the fathering theory is the role of the father as the provider of economic needs. In this role there are 6 indicators with the results of all indicators having the highest proportion of options always. In Table 1, the choice of always having the highest proportion is in the father's indicator working hard to meet the needs of the child $(86.8 \%)$. This means that in the nuclear family it places the father as the primary responsibility for the provision of economic needs. 
Table 1 Distribution of examples based on the role of the father as a leader and provider of economic needs

\begin{tabular}{|c|c|c|c|c|c|c|c|}
\hline & Indicator & Never (\%) & $\begin{array}{c}\text { Rarely } \\
\text { once (\%) }\end{array}$ & $\begin{array}{l}\text { Sometimes } \\
(\%)\end{array}$ & $\begin{array}{l}\text { Often } \\
(\%)\end{array}$ & $\begin{array}{l}\text { Always } \\
(\%)\end{array}$ & $\begin{array}{c}\text { Index } \\
(0.0- \\
100,0)\end{array}$ \\
\hline \multicolumn{8}{|c|}{ Father as leader } \\
\hline 1 & $\begin{array}{l}\text { Implementing the five } \\
\text { time prayers }\end{array}$ & 1.4 & 6.0 & 8.8 & 12.0 & 71.8 & 86.0 \\
\hline 2 & $\begin{array}{l}\text { Pleasure to read Al- } \\
\text { Qur'an }\end{array}$ & 4.0 & 13.6 & 28.4 & 28.0 & 26.0 & 60.9 \\
\hline 3 & $\begin{array}{l}\text { Reminding children to } \\
\text { pray }\end{array}$ & 2.2 & 13.6 & 28.4 & 28.0 & 26.0 & 83.2 \\
\hline 4 & $\begin{array}{l}\text { Sanction if the child } \\
\text { leaves the prayer }\end{array}$ & 14.4 & 8.0 & 21.4 & 26.0 & 30.2 & 59.0 \\
\hline 5 & $\begin{array}{l}\text { Be affectionate and } \\
\text { fair to the child }\end{array}$ & 1.6 & 4.4 & 11.0 & 22.0 & 61.0 & 82.5 \\
\hline 6 & $\begin{array}{l}\text { Pray for the good of } \\
\text { the children }\end{array}$ & 1.4 & 2.0 & 2.2 & 13.2 & 81.2 & 92.6 \\
\hline 7 & $\begin{array}{l}\text { Proper to imitated and } \\
\text { exempiflied by } \\
\text { children }\end{array}$ & 9.8 & 15.0 & 18.6 & 20.8 & 35.8 & 63.6 \\
\hline 8 & $\begin{array}{l}\text { Retrieving school } \\
\text { report of children }\end{array}$ & 31.4 & 11.4 & 22.8 & 15.6 & 18.8 & 41.9 \\
\hline 9 & $\begin{array}{l}\text { Reprimand and } \\
\text { sanction if the child } \\
\text { commits a violent act }\end{array}$ & 6.2 & 3.4 & 9.4 & 28.0 & 53.0 & 78.0 \\
\hline \multicolumn{8}{|c|}{$\begin{array}{l}\text { Dad as a provider of } \\
\text { economic needs }\end{array}$} \\
\hline 1 & $\begin{array}{l}\text { Adequate feeding } \\
\text { needs of children } \\
\text { every day }\end{array}$ & 2.4 & 4.0 & 12.4 & 21.4 & 59.8 & 80.95 \\
\hline 2 & $\begin{array}{l}\text { Sufficient child's } \\
\text { learning needs }\end{array}$ & 3.8 & 4.2 & 10.8 & 27.2 & 54.0 & 79.2 \\
\hline 3 & $\begin{array}{l}\text { Giving pocket money } \\
\text { as needed }\end{array}$ & 3.6 & 5.6 & 13.4 & 20.2 & 57.2 & 78.5 \\
\hline 4 & $\begin{array}{l}\text { Pay and pay off the } \\
\text { child's school fees }\end{array}$ & 4.4 & 4.6 & 17.6 & 23.8 & 49.6 & 74.1 \\
\hline 5 & $\begin{array}{l}\text { Fathers' income is } \\
\text { able to meet the needs } \\
\text { of children and } \\
\text { families }\end{array}$ & 2.4 & 4.6 & 13.0 & 22.8 & 57.2 & 79.8 \\
\hline 6 & $\begin{array}{l}\text { Dad worked hard to } \\
\text { meet the needs of } \\
\text { children }\end{array}$ & 1.4 & 1.0 & 2.4 & 8.4 & 86.8 & 94.2 \\
\hline
\end{tabular}

More than half of teenagers stated that fathers always meet the daily needs of children (59.8\%). always meet the learning needs of children $(54.0 \%)$. always provide pocket money as needed (57.2\%). and father's income is always able to meet the needs of children and families (57.2\%). Meanwhile. as many as 49.6 percent of the instances state that fathers always pay and pay the school fees for children.

Based on the index. the index with the highest indicator. ie the father worked hard to meet the needs of children (94.2). Meanwhile. the lowest index is in the indicator of pay and pay school fees for children (74.1). This means that the father not 
only provides for the child's need to pay for school fees. but other children's needs in general. such as those related to the facilities required by the child.

\section{Dimensions of Father's Role as Protector (Protector)}

In the father's role dimension as a protector. there are seven indicators that show the role of father as protector. The results in Table 2 show that the largest percentage of the answers for all indicators are always on choice. Most fathers always remind children not to fall into deviant behavior such as drinking alcohol. drugs. and promiscuity (83.4\%). More than half of the examples This means the father is positioned as the first and main protector in the nuclear family. The indicator with the highest index is to remind the child not to fall into deviant behavior such as drinking alcohol. drugs. and promiscuity (90.9). An increasingly free association and the internet that can also affect the child's behavior. so that the father always reminds his son to prevent the deviant behavior that occurred in his son.

Table 2 Distribution of examples based on the role of father as protector

\begin{tabular}{|c|c|c|c|c|c|c|c|}
\hline No & Indicator & $\begin{array}{l}\text { Never } \\
(\%)\end{array}$ & $\begin{array}{l}\text { Rarely } \\
\text { once } \\
(\%)\end{array}$ & $\begin{array}{l}\text { Sometimes } \\
(\%)\end{array}$ & $\begin{array}{l}\text { Often } \\
(\%)\end{array}$ & $\begin{array}{l}\text { Always } \\
(\%)\end{array}$ & $\begin{array}{c}\text { Index } \\
(0.0- \\
100,0)\end{array}$ \\
\hline 1 & $\begin{array}{l}\text { Child feels secure with the } \\
\text { presence of the father }\end{array}$ & 1.6 & 3.8 & 8.4 & 15.4 & 70.8 & 86.3 \\
\hline 2 & $\begin{array}{l}\text { Children like at home and } \\
\text { comfort when the father is at } \\
\text { home }\end{array}$ & 2.4 & 7.6 & 22.2 & 22.6 & 45.2 & 71.5 \\
\hline 3 & $\begin{array}{l}\text { Fathers take care of the health } \\
\text { and safety of children }\end{array}$ & 1.0 & 3.6 & 5.0 & 17.6 & 72.8 & 89.0 \\
\hline 4 & $\begin{array}{l}\text { Fathers care (worrying) } \\
\text { children when getting } \\
\text { problems }\end{array}$ & 5.4 & 10.4 & 19.2 & 23.4 & 41.6 & 69.1 \\
\hline 5 & $\begin{array}{l}\text { Father reminds children not to } \\
\text { engage in brawl }\end{array}$ & 8.2 & 2.8 & 2.2 & 12.6 & 74.2 & 85.6 \\
\hline 6 & $\begin{array}{l}\text { Reminding children not to fall } \\
\text { prey to deviant behavior such } \\
\text { as drinking alcohol. drugs. and } \\
\text { promiscuity }\end{array}$ & 4.6 & 1.2 & 2.4 & 8.4 & 83.4 & 90.9 \\
\hline 7 & $\begin{array}{l}\text { Reminding children not to } \\
\text { waste time with unwanted } \\
\text { activities such as play games. } \\
\text { playstations. and mobile }\end{array}$ & 3.6 & 3.0 & 8.4 & 24.8 & 60.2 & 82.4 \\
\hline
\end{tabular}

\section{Dimensions of Father's Role as Educator}

Indicators indicating the role of father as educator amount to eight indicators with five indicators have the highest proportion of choices always. In Table 3 . the indicators with the highest proportion are occasionally giving praise or rewards when the child performs $(27.8 \%)$. sometimes guiding and supporting the child in completing schoolwork $(27.8 \%)$. and never educating children in sexual problems correctly (48.4\%). This suggests that the role of the father as educator is not the primary responsibility. and it is assumed that the role of educators in the nuclear family is mostly done by the mother. 
Based on the index. the highest index indicator is taught moral children or courtesy ethics in teachers and older people (92.2). then reminds children to be careful in association with the opposite sex (90.8). Meanwhile. the indicator with the lowest low index value is related to properly educating children in sexual matters (33.2). This suggests that. the topic of sexual problems is still considered taboo discussed by the father to his son. The impact is the child will get the information from other sources. The next lowest index value is on indicators giving praise or rewards when the child performs (51.2) and guiding and supporting the child in completing the school learning task (53.3).

Table 3 Distribution of examples based on the role of father as educator

\begin{tabular}{|c|c|c|c|c|c|c|c|}
\hline No & Indicator & $\begin{array}{l}\text { Never } \\
(\%)\end{array}$ & $\begin{array}{l}\text { Rarely } \\
\text { once } \\
(\%)\end{array}$ & $\begin{array}{l}\text { Sometimes } \\
(\%)\end{array}$ & $\begin{array}{c}\text { Often } \\
(\%)\end{array}$ & $\begin{array}{l}\text { Always } \\
(\%)\end{array}$ & $\begin{array}{l}\text { Index } \\
(0.0- \\
100,0) \\
\end{array}$ \\
\hline 1 & $\begin{array}{l}\text { Guiding children to worship } \\
\text { and reciting the Qur'an }\end{array}$ & 6.8 & 11.6 & 21.0 & 23.0 & 37.6 & 65.9 \\
\hline 2 & $\begin{array}{l}\text { Teaching a moral child or } \\
\text { courtesy ethic to teachers and } \\
\text { older people }\end{array}$ & 0.8 & 1.8 & 3.0 & 15.2 & 79.2 & 92.2 \\
\hline 3 & $\begin{array}{l}\text { Remind the child to be careful } \\
\text { in association with the opposite } \\
\text { sex }\end{array}$ & 1.6 & 3.0 & 2.2 & 17.8 & 75.4 & 90.8 \\
\hline 4 & Remind the child time to learn & 4.8 & 9.2 & 22.6 & 28.6 & 34.8 & 66.5 \\
\hline 5 & $\begin{array}{l}\text { Give praise or reward when the } \\
\text { child achieves }\end{array}$ & 11.4 & 15.0 & 33.0 & 20.4 & 20.2 & 51.2 \\
\hline 6 & $\begin{array}{l}\text { Educate children in sexual } \\
\text { problems correctly }\end{array}$ & 12.6 & 16.4 & 27.8 & 20.2 & 23.0 & 53.3 \\
\hline 7 & $\begin{array}{l}\text { Educate children in sexual } \\
\text { problems correctly }\end{array}$ & 48.4 & 9.4 & 14.0 & 12.6 & 15.6 & 33.2 \\
\hline 8 & $\begin{array}{l}\text { Educate children to be socially } \\
\text { savvy }\end{array}$ & 9.4 & 8.0 & 18.2 & 24.2 & 40.2 & 66.9 \\
\hline
\end{tabular}

\section{Role of Father as Playing Friends (Playmates)}

In the role dimension of the father as a playmate. there are three indicators that most are always in the choice always (Table 4). The highest percentage for choice is always among the three indicators is to make the child happy and happy from childhood (54.8\%). Meanwhile. two other indicators are taking children on a holiday day. which has the most percentage of the occasional choice $(41.4 \%)$. and the highest percentage for indicators to invite children to exercise such as cycling and others is on the choice sometimes $(32.6 \%)$. The highest index value of the father's dimension as a playmate is on the indicator of making the child happy and happy from childhood (78.3). These results indicate that in childhood. the father becomes a playmate that is fun for a child and participates in parenting. Meanwhile. the lowest index value is shown in the indicators to invite children to exercise such as cycling (34.6) and take children on holiday (42.1).

\section{Role of Father as Friend}

The results showed that the role of father as a friend in the child's perception was shown by always providing time for children and families to gather like eating together and watching television (36.6\%) and making children feel comfortable speaking open 
(38.0\%). In addition. the father also likes to invite children to discuss lightly or casually chat $(26.0 \%$ sometimes. $26.0 \%$ often) and make the child feel comfortable speaking openly (23.0\% sometimes. $23.0 \%$ often). Furthermore. as many as 32.6 percent of children say the father sometimes listens and responds to the child when complaining about problems / vent. The same percentage is also found for the statement that the father never listens and responds to the child when he / she complains about the problem.

Table 4 Sample distribution based on the role of the father as a playmate and as a friend

\begin{tabular}{|c|c|c|c|c|c|c|c|}
\hline No & Indicator & $\begin{array}{l}\text { Never } \\
(\%)\end{array}$ & $\begin{array}{l}\text { Rarely } \\
\text { once } \\
(\%) \\
\end{array}$ & $\begin{array}{l}\text { Sometimes } \\
(\%)\end{array}$ & $\begin{array}{c}\text { Often } \\
(\%)\end{array}$ & $\begin{array}{l}\text { Always } \\
(\%)\end{array}$ & $\begin{array}{c}\text { Index } \\
(0.0- \\
100,0) \\
\end{array}$ \\
\hline \multicolumn{8}{|c|}{ Dad as a playmate } \\
\hline 1 & $\begin{array}{l}\text { Take the time to play with } \\
\text { children }\end{array}$ & 5.4 & 13.4 & 23.8 & 22.4 & 35 & 64.4 \\
\hline 2 & $\begin{array}{l}\text { Fathers developed } \\
\text { communication and warm } \\
\text { relationships with jokes and jokes }\end{array}$ & 4.2 & 8.4 & 21 & 27 & 39.4 & 69.1 \\
\hline 3 & $\begin{array}{l}\text { Invite children to travel on } \\
\text { holiday }\end{array}$ & 13 & 20.4 & 41.4 & 14.6 & 10.6 & 42.1 \\
\hline 4 & $\begin{array}{l}\text { Inviting children to exercise such } \\
\text { as cycling etc }\end{array}$ & 27.4 & 21.4 & 32.6 & 11.2 & 7.4 & 34.6 \\
\hline 5 & $\begin{array}{l}\text { Making children happy and happy } \\
\text { since childhood }\end{array}$ & 4.8 & 9.4 & 8.8 & 22.2 & 54.8 & 78.3 \\
\hline \multicolumn{8}{|c|}{ Father as a friend } \\
\hline 1 & $\begin{array}{l}\text { Provide time for children and } \\
\text { families to gather like eating } \\
\text { together. watching television etc. }\end{array}$ & 6.0 & 13.0 & 21.0 & 23.4 & 36.6 & 65.9 \\
\hline 2 & $\begin{array}{l}\text { Likes to invite children to have a } \\
\text { light discussion or a casual } \\
\text { conversation }\end{array}$ & 7.0 & 15.0 & 26.2 & 26.0 & 25.8 & 59.3 \\
\hline 3 & $\begin{array}{l}\text { Make the child feel comfortable } \\
\text { speaking open }\end{array}$ & 4.0 & 10.6 & 23.6 & 23.8 & 38.0 & 67.0 \\
\hline 4 & $\begin{array}{l}\text { Listening and responding to } \\
\text { children when complaining about } \\
\text { problems / vent }\end{array}$ & 32.6 & 17.0 & 32.6 & 7.6 & 10.2 & 32.2 \\
\hline 5 & $\begin{array}{l}\text { Helping children solve problems } \\
\text { when facing conflict with their } \\
\text { friends }\end{array}$ & 26.0 & 15.0 & 26.8 & 16.4 & 15.8 & 42.3 \\
\hline
\end{tabular}

Based on the index. the highest indicator is to make the child feel comfortable speaking open (67.0). This suggests that the majority of fathers always make their children feel comfortable speaking openly. Meanwhile. the lowest index indicator is listening and responding to children when complaining about problems or vent (32.2). meaning that this indicator is still sometimes or even never done by the father. If you look at the highest index is to make the child feel comfortable to talk comfortable. while the lowest index is to listen and respond to the child when complaining about problems or vent. then the father should play a good listener also so that children still want to talk open every problem to his father (Table 4) . 


\section{Comparison of Results Question Six Dimensions of Father's Role.}

Based on the results shown in Table 5. of the six dimensions of the father role studied. the highest index averages are in the father's role dimension as a protector (82.13) than any other dimension. The next highest index is in the dimensions of the father role as the provider of economic needs. Meanwhile. the dimension with the lowest index average is the role of the father as a friend (53.43). The next lowest index value is the role of the father as a playmate (57.73).

Table 5 Comparison of the six dimensions of the father role to the child in the Islamic perspective

\begin{tabular}{clc}
\hline No & \multicolumn{1}{c}{ Dimension of Father's Role } & Mean of Index $(0.0-100.0)$ \\
\hline 1 & Leader & 71.98 \\
2 & Provider of economic needs & 81.14 \\
3 & Protector & 82.13 \\
4 & Educators & 65.02 \\
5 & Playing Friends & 57.73 \\
6 & Companions & 53.43 \\
\hline
\end{tabular}

\section{Discussion}

The study found that children have a perception that the greatest role of fathers in a child's life is the role of leader, provider of economic needs, and protector. In this study, children see the father as a leader in guiding and performing worship. The child also has a perception that the role of the father as a leader is seen when the father can show a loving and just attitude, and apply discipline to the child. The role of the father as a source of economic and psychological support, protectors, companions, and counselors is essential for the development of healthy children (Arditti et al., 2014).

The role of the father as a provider of economic needs is seen from how hard work father in fulfilling all the needs of children such as food and education needs. The economic support of fathers contributes positively to the development of children because working fathers can be positive examples for children (NCES, 2001). Father's ability to play her role as an economic provider for the family contributes to improving the quality of life of children (Ball, Moselle, \& Pederen, 2007). The working dad has a better relationship with his children than the unemployed father (Rosenberg \& Wilcox, 2006).

The study also found that the father's role as a protector is seen in how fathers guide children to own and apply good behaviors in everyday life. Children also have the perception that the role of father as a protector is seen when the father can make the child feel comfortable around father, and when the father can maintain the health and safety of children. Adolescents close to fathers are less likely to engage in the use of drugs and lower the risk of having health problems (Ball, Moselle, \& Pederen, 2007). The proximity of fathers and children in adolescence is related to the satisfaction of a child's life as an adult (Lamb \& Lewis, 2004).

Children have a perception that the role of father as educator, playmate, and best friend still not too big in child life. In this study, children have a perception that the role of father as educator is still low, especially related to sexual education, mentoring in learning, and providing motivation to learn. Previous research has found that children 
with involved and responsible fathers of education have a high probability of achievement in school (Ransaw, 2014).

In this study, the role of fathers as friends and friends is still low, especially related to the time spent together and communication built with children. Previous research has found that compared to mother-child relationships, the father-son relationship is related to the development of the child when the child is in high school (Lamb \& Lewis, 2004). Previous research has also found that the quality of play between father and child in the first 13 years of a child's life can predict a sense of selfesteem in adolescents (Grossmann et al., 2002).

The results of this study indicate that the role of the father in the child's life is still not too big, especially related to the role as educators, playmates, and friends. Therefore, it is important to do further research to find out what factors can strengthen the role of the father, especially in the dimensions of the father role is still low, namely the role as educators, playmates and friends for children. This is important considering that based on previous studies such as those conducted by Kurk (2015), Natasha J. Cabrera (2002), Adams (2015), Clark (2009) and others have proven the magnitude of the positive influence of father involvement on children, both to intellectual aspects and academic success, as well as to the mental, psychological and social intelligence of children. Similarly, the results of the study of Muslim scholars and intellectuals such as Ibn Qayyim (2001), Ulwan (2013), and Baharits (1991) which provide the basis and proof of the importance of the role of the father of the children of Islam.

\section{Conclusion}

\section{Conclusion and Suggestion}

The role of the father as the leader, the provider of economic needs, and the protector is the greatest role dimension the child perceives in life. The role of the father as a leader is seen when the father can be a guide in performing worship, showing affection and fair attitude, and applying discipline to the child. The role of the father as the provider of economic needs is seen when the father works hard to meet all the needs of the child, the father's role as a protector is seen when the father can guide the child to have and apply good behaviors, make the child feel comfortable around father, and maintain health and safety child. Meanwhile, the role that the child feels less done by the father is the role as educator, playmate, and best friend. As an educator, the father can not play a role in providing sexual education, mentoring in learning, and providing motivation to learn. As a playmate and a best friend, dad lacks time together with children and less communication with children.

\section{Suggestion}

Every parent especially father need to understand the importance of father role in child development. Increasing knowledge and understanding about the importance of father role to children can be done through the provision of parenting education programs (training, seminars, and counseling) to parents, especially fathers. Scholars, educated figures and Muslims can provide knowledge and understanding of the importance of the role of the father from the viewpoint of Islam through lectures and other religious activities in mosques, majlis taklim, and other places where religious activities are often performed. Academics and researchers need to do more research to find out how far the role of father to various aspects of life such as attitudes and 
morality, achievement, intellectual intelligence, emotional and social intelligence, and other aspects. The results of this study can also be taken into consideration and reference for policy makers in making policies that allow a father to perform its role maximally.

\section{Reference}

Abadzhah, N. (2007). Bilik-bilik cinta Muhammad: Kisah sehari-hari rumah tangga nabi. Jakarta: Zaman.

Al-Bukhari, A. A. M., bin Ismail. (2014). Shahih bukhari. Kairo: Syirkah al-Quds.

Al-Jauziyah, Ibnu Qayyim. (2005).Tuhfat al-Maudud Bi Ahkam al-Maulud, Takhrij Muhammad Nashiruddin Al-Albani, Kairo: Dar al-Atsar

Arditti, J. A., Kennington. M., Grzywacz, J. G., Jaramillo, A., Isom, S., Quandt, S. A., \& Arcury, T. A. (2014). Fathers in the fields: father involvement among latino migrant farmworkers. Journal of Comparative Family Studies, 45(4), 537-557.

Baharits, A. H. S. (1991). Mas'uliyat Al-Ab al-Muslim Fi Tarbiyat al-Walad Fi Marhalat Al-Tufulah. Jeddah: Darul Mujtama.

Ball, J., Moselle, K., \& Pedersen, S. (2007). Father's involvement as a determinant of child health (Report). Diambil dari http://www.ecdip.org/docs/pdf/PH\%20FI\%20Final\%20Full\%20Report.pdf.

Belsky, A. Jaim, J. \& K. Crcnic. (2015). Beyond fathering behaviors: Types of dads. Journal Family Pshchology, 5. Diambil dari http://www.questio.com. [diunduh 10 Des 2015].

Brown, T. (2000). What Special about Father's, Involvement? Diambil dari http://www.balconesbank. community.com/voices/father.asp. [diunduh 10 Des 2015].

Cabrera, N. (2005). Father involvement: Models and theoritical frameworks. In N. J. Salkind (Ed.), Macmillan Psychology Reference Series, Vol.1: Child Development (pp.143-158). New York: Macmillan Reference USA.

Darity, W. A., Jr. (2008). International encyclopedia of sicial sciences, Vol 2. Detroit: Macmillan References USA.

Erawati, M. (2012). Model keterlibatan ayah dalam pengasuhan. Jurnal Mudarrisa, 1(1). Diambil dari http://eprints.stainsalatiga.ac.id/id/eprint/1.

Evans, G.D., \& Fogarty, K. (1999). The common roles of fahers: The five Ps. University of Florida. Diambil dari http://edis.ifas..ufl..edu/Body HE137. [diunduh 10 Des 2015].

Grossmann, K., Grossmann, K. E., Fremmer-Bombik, E., Kindler, H., ScheuererEnglisch, H., \& Zimmermann, P. (2002). The uniqueness of the child-father attachment relationship: Fathers' sensitive and challenging play as a pivotal variable in a 16-year longitudinal study. Social Development, 11(3).

Hilliard, D.R. (1996). Qualities of successfull father-child relationship. Diambil dari http://www.YouthandReligion.org/Resources/ref age.htm/. [diunduh 10 Des 2015].

Kurk, E. (2012, May 23). Father absence, father deficit, father hunger the vital importance of paternal presence in children's lives. Psychology Today. Diambil dari https://www.psychologytoday.com /blog/co-parenting-afterdivorce/201205/father-absence-father-deficit-father-hunger.

Lamb, M. E., \& Lewis, C. (2004). The development and significance of father-child relationships in two-parent families. Diambil dari 
https://www.researchgate.net/publication/232604349_

The_Role_of_the_Father_An_Introduction.

Lewis, C., \& Lamb, M. E. (2003). Fathers' influences on child development: The evidence from two-parent families. European Journal of Psychology of Education,18 (2), 211-228.

McAdoo, J.L. (1993). The roles of African-American fathers: An ecological perspective. Journal of Contemporary Human Services, 74(1), 28-35.

Muslim, A. A. M., bin Al-Hajjaj Al-Qusyairi An-Naisaburi. (1994). Shahih Muslim. Beirut, Dar al-Fikr.

Nadwi, M. A. (2007). Al-Muhaddithat: The Women Scholar In Islam. London: Interface Publications.

[NHES] National Household Education Survey. (1997). Father's involvement in their's children school (Statistical Analysis Report). U.S Department of Education, Washington, USA. Diambil dari: https://nces.ed.gov/pubs98/98091.pdf.

[NCES] National Center For Education Statistics. (2001). Measuring father involvement in young's children lives; recommendations for fatherhood module for the ECLS$B$ (Working Paper No. 2001-02). U.S. Department of Education, Washington, USA. Diambil dari https://nces.ed.gov/pubs2001/200102.pdf.

[NCOFF] National Center on Father and Families. (2001). Fathering indicator framework: A tool for quantitative and qualitative analysis (Report). Diambil dari http://www.ncoff.qse.upenn.edu/fif /Fof report.pdf. [diunduh 10 Des 2015].

Parke, R. D., \& Mcdowell, D. J. (2003). Fatherhood. In J. J. Ponzetti (Ed.). International Encyclopedia of Marriage and Family, Vol. 2. New York: Macmillan Reference USA.

Ransaw, T. (2014). The good father: african american fathers who positively influence the educational outcomes of their children. A Journal on Black Man, 2(2), 1-25.

Rilley, R. W., \& Shalala, D. E. (2000). A call commitment: Fahers' involvement in children's learning (Report). U.S. Department of Education, Washington, USA. Diambil dari https://www2.ed.gov/pubs/ parents/ calltocommit/fathers.pdf.

Rosenberg, J., \& Wilcox, W. B. (2006). The importance of fathers in the healthy development of children (Report). U.S. Department of Health and Human Services. Diambil dari https://www.childwelfare.gov/pubPDFs/fatherhood.pdf.

Slameto. (2002). Peranan ayah dalam pendidikan anak dan hubungannya dengan prestasi belajarnya. Jurnal Satya Eydaya, 15(1), 15-26.

Sofar, C. C. (2008). Pengembangan karakter melalui pendidikan keluarga; studi komparatif teori al-ghazali dan teori kornadt (Disertasi). Universitas Islam Negeri Jakarta, Jakarta, Indonesia.

Sukmadinata, Nana Syaodih. (2010). Metode Penelitian Pendidikan, Bandung, Rosda Karya

Ulwan, A. N. (2013). Tarbiyat al-Aulad fi al-Islam. Kairo: Dar al-Salam. 